\title{
PHOSPHITE EFFECT ON HOT AND SWEET PEPPER REACTION TO Phytophthora capsici
}

\author{
Fernando Cesar Sala; Cyro Paulino da Costa²*; Márcia de Moraes Echer³ Marise Cagnin \\ Martins $^{4}$; Sally Ferreira Blat ${ }^{1}$ \\ ${ }^{1}$ USP/ESALQ - Programa de Pós-Graduação em Fitotecnia. \\ ${ }^{2}$ USP/ESALQ - Depto. de Produção Vegetal - C.P. 09 - 13418-900 - Piracicaba, SP - Brasil. \\ ${ }^{3}$ UNIOESTE - Centro de Ciências Agrárias - C.P. 1008 - 85960-000 - Marechal Cândido Rondon, PR - Brasil. \\ ${ }^{4}$ USP/ESALQ - Depto. de Entomologia, Fitopatologia e Zoologia Agrícola. \\ *Corresponding author <cpcosta@terra.com.br>
}

\begin{abstract}
Phosphite has been recommended to enhance plant resistance against Phytophthora. This work evaluated the response of hot and sweet pepper (Capsicum annuum L.) to Phytophthora capsici from juvenile up to the adult stage following treatment with phosphite. Sweet pepper hybrids considered to be resistant to P. capsici, like Reinger, Nathalie and Athenas, were evaluated. The susceptible checks were hybrid Magali R and cvs. Myr 10 and Ikeda. Hot pepper Criollo de Morelos 328, CM 334, BGH 3756, BGH 5122, CNPH 294 and Locorte were used as referential resistant lines. Phosphite did not have an effect on the hot pepper resistant lines because of their genetic homozygozity, while no protection was observed for the Athenas hybrid claimed to be resistant. Heterozygous hybrids recognized as resistant, like Reinger and Nathalie, showed higher survival following phosphite treatment, and their reaction was equivalent to the resistant cvs. CM 328 and CM 334, except for the fruiting stage. Depending of the hybrid heterozygous genotype, phosphite possibly acts through indirect phytoalexin induction through the inhibited pathogen.
\end{abstract}

Key words: Capsicum, phosphorous acid, resistance induction genetic, pepper crown root rot

\section{EFEITO DO FOSFITO NA REAÇÃO DE PIMENTÃO E PIMENTEIRA A Phytophthora capsici}

\begin{abstract}
RESUMO: Fosfito tem sido recomendado para aumentar o sistema de resistência de plantas atacadas por fitopatógenos. Este trabalho avaliou a ação do fosfito nas reações de pimentão e pimenteiras (Capsicum annuum L.) a Phytophthora capsici na fase juvenil até a fase adulta, tratadas com fosfito. Os híbridos de pimentão considerados resistentes a $P$. capsici foram Reinger, Nathalie e Athenas, enquanto que o híbrido Magali R e as cvs. Myr 10 e Ikeda constituíram as referenciais suscetíveis. As linhagens de pimenta Criollo de Morelos 328, CM 334, BGH 3756, BGH 5122, CNPH 294 e Locorte, foram usadas como padrão referencial de resistência ao patógeno. O fosfito não afetou a reação das linhagens resistentes devido sua homozigosidade genética. Não houve ação protetora do fosfito nos hospedeiros suscetíveis, inclusive no híbrido Athenas. Os híbridos heterozigotos considerados resistentes, como Nathalie e Reinger, tiveram uma sobrevivência equivalente ao CM 328 e 334, mas sua reação de resistência não persistiu na fase de pós-transplante. Possivelmente, o fosfito age através da indução da produção de fitolexinas no hospedeiro indiretamente por meio do patógeno inibido.

Palavras-chave: Capsicum, ácido fosforoso, indução de resistência genética, podridão de raízes do pimentão
\end{abstract}

\section{INTRODUCTION}

Crown root rot of hot and sweet peppers (Capsicum annuum L.), caused by Phytophthora capsici Leonian, is one the most destructive diseases in some regions of Brazil (Matsuoka et al., 1984) as well in other countries (Kimble \& Grogan, 1960; Barksdale et al., 1984). The disease can be controlled by the systemic fungicide metalaxyl, but it is expensive and vulnerable to pathogen resistance (Hwang \& Kim, 1995; Matheron \& Matejka, 1995). Genetic resistance would be the best Phytophthora management control when integrated with chemical and cultural pratices to reduce soil moisture
(Bartual et al., 1991; Reifschneider et al., 1992; Ristaino \& Johnston, 1999).

The resistance mechanism to $P$. capsici involves accumulation of the phytoalexin capsidiol, which may play an important role in the host defense response (Hwang \& Sung, 1989; Candela et al., 1995). Phosphite has been recommended as a plant protectant (Fenn \& Coffey, 1984; Rohrbach \& Schenck, 1985; Guest \& Grant, 1991; Wilkinson et al., 2001) and inducer of host resistance against Phytophthora (Pegg et al., 1985; Smillie et al., 1989; Candela et al., 1995; Jackson et al., 2000). Fitofós, a commercial phosphite formulation, is considered to stimulate phytoalexin production, inhibit- 
ing and arresting pathogen development and enhancing host defense mechanism (Guest, 1984; 1986; Saindrenan et al., 1988).

Jackson et al. (2000) studied the effect of phosphite on Eucalyptus marginata clones inoculated with $P$. cinnamomi. They found an inhibitory effect of pathogen development in the host roots. The pathogen, arrested in the host by phosphite, possibly elicits host phytoalexin as a defense a mechanism. Sweet and hot pepper resistance screening to $P$. capsici is highly dependent on plant age. Inoculation made at seedling stage may breakdown the resistance (Reifschneider et al., 1986; Echer, 2001). Adult plant resistance to Phytophthora is shown only after 60 days of age.

The present work aimed to: (i) to determine the effect of phosphite on suscepthility of sweet and hot pepper to $P$. capsici; (ii) to establish an eventual selective resistance protocol using phosphite to enhance juvenile stage genetic resistance; and (iii) to check the phosphite effect and its interaction with the adult plant genetic reaction resistance, until fruiting.

\section{MATERIAL AND METHODS}

Hot peppers CM 328, CM 334, BGH 3756, BGH 5122, CNPH 294, Locarte (Sala et al., 2001) and the commercial sweet pepper hybrids Athenas, Nathalie and Reinger, were used as resistant referential, while Magali $\mathrm{R}$ hybrid and cvs. Myr 10 and Ikeda were used as susceptible checks. Two experiments were carried out. The first experiment, tested the effect of phosphite on resistant $P$. capsici lines. Resistant and susceptible checks were inoculated at either 44 or 80 days after seedling (DAS). Both sets of plants ages were inoculated using speedling trays with 128 and 72 cells, respectively. Resistant and susceptible checks were submitted to four treatments: phosphite and $P$. capsici inoculation; phosphite without inoculation; no phosphite and P. capsici inoculation, and no phosphite and no inoculation, in a randomized block experimental design with three replication. Plants that survived with phosphite treatment were then transplanted to pots (five plants per pot) with $5 \mathrm{~L}$ substrate, and two treatments were made to evaluate post transplant treatments with phosphite. The weekly dosage was $1 \mathrm{~mL} \mathrm{~L}^{-1}$ Fitofós $\mathrm{K}$ by drenching each pot, in a completely randomized experimental design with three replications.

\section{Phosphite application}

Fitofós K (00-30-20) was used as phosphite source containing mono di-potassium phosphonate with $50 \% \mathrm{H}_{3} \mathrm{PO}_{3}$. Seedlings were drenched by $0.5-\mathrm{L}$ trays with a phosphite solution $\left(4 \mathrm{~mL} \mathrm{~L}^{-1}\right)$, five days before the pathogen inoculation. Eight days after inoculation (DAI), the weekly phosphite drench dosage was reduced to $1 \mathrm{~mL} \mathrm{~L}^{-1}$. Phosphite was applied at the juvenile stage when plants had five to six true leaves. Phosphite treatment was kept up to full bloom and fruiting stage. In the second trial, surviving plants were transplanted, and phosphite application was repeated weekly with a drench of $1 \mathrm{~mL} \mathrm{~L}^{-1}$ (0.5 L per pot) up to fruit development stage.

\section{Phytophthora capsici inoculum}

The Phytophthora capsici isolate PPc01-99 used in this study was obtained from diseased sweet pepper plants growing in commercial fields. The pathogen was isolated on water agar, transferred to potato-dextrose-agar (PDA), and propagated on cucumber fruit: 5-mm diameter holes were punched then filled with a PDA disc from a pure culture, and incubated in a humid chamber for 48 hours at $23-30^{\circ} \mathrm{C}$ under fluorescent light to induce sporangia formation. To induce zoospore release, mycelia and sporangia were gently scraped off into Petri dishes with de-ionized water for 40 minutes at $10^{\circ} \mathrm{C}$. The number of zoospore $\mathrm{mL}^{-1}$ was determined by direct count in hemacytometer. The inoculum was diluted to $5 \times 10^{3}$ zoospores $\mathrm{mL}^{-1}$.

\section{Inoculation method and evaluation criteria}

Plants were inoculated by drenching $2 \mathrm{~mL}$ of spore inoculum for each plant. Disease developed as stem necroses, wilting or death until 13 days after inoculation. Statistical analysis was made on factorial scheme $12 \times 2$ $\times 2$ (variety, phosphite and pathogen) for the first stage (juvenile and adult plant stage), and a factorial scheme 8 $\times 2$ and $9 \times 2$ (variety and phosphite) for the second stage juvenile and adult stage trial, respectively. Data were submitted to analysis of variance and comparisons of means by Tukey test ( $\alpha=0.05$ ) using SAS statistical program. Uninoculated plants with and without phosphite and with $100 \%$ survival were not considered for statistical analyses.

\section{RESULTS AND DISCUSSION}

Criollo de Morelos 328 and CM 334 were $100 \%$ resistant up to the final fruiting stage regardless of phosphite application. Criollo de Morelos is a Mexican hot pepper widely known to be the most consistent resistance source to Phytophthora capsici (Ortega et al., 1986; Bosland \& Lindsey, 1991). Resistant cvs. from the USP/ESALQ Capsicum germoplasm collection (BGH 3756, BGH 5122, CNPH 294, and Locarte), were also 100\% resistant (Sala et al., 2001), until the final fruiting stage. Susceptible checks F1 Magali R, cvs. Myr 10, and Ikeda, did not survive and were killed by $P$. capsici whether treated with phosphite or not (Table 1). Phosphite enhanced the survival of heterozygous sweet pepper hybrids claimed to be resistant to $P$. capsici. 
Table 1 - Survival of sweet and hot peppers (average of three repetitions) treated with phosphite and inoculated with Phytophthora capsici 44 and 80 days after sowing (DAS) and the effect of the phosphite after-transplant. Piracicaba, SP. 2001.

\begin{tabular}{|c|c|c|c|c|c|c|c|}
\hline \multirow{3}{*}{ Genotype } & & & & & \multicolumn{3}{|c|}{ After-transplant } \\
\hline & \multicolumn{2}{|c|}{$44 \mathrm{DAS}^{1}$} & \multicolumn{2}{|c|}{$80 \mathrm{DAS}^{2}$} & \multirow[t]{2}{*}{ 44DAS* } & \multicolumn{2}{|c|}{ 80DAS } \\
\hline & Phosphite & No phosphite & Phosphite & No phosphite & & Phosphite & No phosphite \\
\hline \multicolumn{8}{|c|}{$\%$ of survival } \\
\hline CM 328 & $100.00 \mathrm{Aa}$ & $100.00 \mathrm{Aa}$ & $100.00 \mathrm{Aa}$ & $100.00 \mathrm{Aa}$ & $100.00 \mathrm{~A}$ & $100.00 \mathrm{Aa}$ & $100.00 \mathrm{Aa}$ \\
\hline CM 334 & $100.00 \mathrm{Aa}$ & $100.00 \mathrm{Aa}$ & $100.00 \mathrm{Aa}$ & $100.00 \mathrm{Aa}$ & $100.00 \mathrm{~A}$ & $100.00 \mathrm{Aa}$ & $100.00 \mathrm{Aa}$ \\
\hline F1 Athenas & $8.30 \mathrm{Ca}$ & $2.00 \mathrm{Cb}$ & $89.30 \mathrm{Ba}$ & $5.10 \mathrm{Db}$ & - & $0 \mathrm{Ca}$ & $0 \mathrm{Ba}$ \\
\hline F1 Nathalie & $38.50 \mathrm{Ba}$ & $26.00 \mathrm{Bb}$ & $100.00 \mathrm{Aa}$ & $77.80 \mathrm{Cb}$ & $6.70 \mathrm{C}$ & $0 \mathrm{Ca}$ & $6.70 \mathrm{Ba}$ \\
\hline F1 Reinger & $50.00 \mathrm{Ba}$ & $12.50 \mathrm{BCb}$ & $100.00 \mathrm{Aa}$ & $88.90 \mathrm{Bb}$ & $23.30 \mathrm{~B}$ & $33.30 \mathrm{Bb}$ & $0.00 \mathrm{Ba}$ \\
\hline BGH 3756 & $100.00 \mathrm{Aa}$ & $100.00 \mathrm{Aa}$ & $100.00 \mathrm{Aa}$ & $100.00 \mathrm{Aa}$ & $100.00 \mathrm{~A}$ & $100.00 \mathrm{Aa}$ & $100.00 \mathrm{Aa}$ \\
\hline BGH 5122 & $100.00 \mathrm{Aa}$ & $100.00 \mathrm{Aa}$ & $100.00 \mathrm{Aa}$ & $100.00 \mathrm{Aa}$ & $100.00 \mathrm{~A}$ & $100.00 \mathrm{Aa}$ & $100.00 \mathrm{Aa}$ \\
\hline CNPH 294 & $100.00 \mathrm{Aa}$ & $100.00 \mathrm{Aa}$ & $100.00 \mathrm{Aa}$ & $100.00 \mathrm{Aa}$ & $100.00 \mathrm{~A}$ & $100.00 \mathrm{Aa}$ & $100.00 \mathrm{Aa}$ \\
\hline cv. Locarte & $100.00 \mathrm{Aa}$ & $100.00 \mathrm{Aa}$ & $100.00 \mathrm{Aa}$ & $100.00 \mathrm{Aa}$ & $100.00 \mathrm{~A}$ & $100.00 \mathrm{Aa}$ & $100.00 \mathrm{Aa}$ \\
\hline F1 Magali R & $0 \mathrm{Ca}$ & $0 \mathrm{Ca}$ & $0 \mathrm{Ca}$ & $0 \mathrm{Ca}$ & - & - & - \\
\hline cv. Myr 10 & $0 \mathrm{Ca}$ & $0 \mathrm{Ca}$ & $0 \mathrm{Ca}$ & $0 \mathrm{Ca}$ & - & - & - \\
\hline cv. Ikeda & $0 \mathrm{Ca}$ & $0 \mathrm{Ca}$ & $0 \mathrm{Ca}$ & $0 \mathrm{Ca}$ & - & - & - \\
\hline C.V. & $6.73 \%$ & $6.73 \%$ & $4.05 \%$ & $4.05 \%$ & $8.98 \%$ & $11.18 \%$ & $11.18 \%$ \\
\hline
\end{tabular}

Averages followed of same letter, capital letter in the columns and small letter in the lines, do not differ (Tukey, 0.05). ${ }^{1}$ Plants inoculated with Phytophthora capsici to the 44 days after the sowing (DAS); ${ }^{2}$ Plants inoculated with P. capsici to the 80 days after the sowing (DAS);

* No difference between treatment; C.V. - variation coefficient.

Plant age played important role for the phosphite enhancement of $P$. capsici hybrid resistance. Athenas hybrid seedlings 44 DAS were not protected by phosphite, while Nathalie and Reinger had intermediate survival $38.5 \%$ and 50\%, respectively. Phosphite was not effective against $P$. capsici on Nathalie and Reinger after transplant.

Plant age was critical to enhance host resistance to $P$. capsici because hybrid survival 80 DAS was higher when using phosphite. This result agrees with observations of Reifschneider et al. (1986) and Echer (2001) about adult plant resistance to P. capsici. Phosphite enhanced resistance to $P$. capsici of Nathalie and Reinger hybrids up to equivalent CM 328 and 334 level. Resistance to P. capsici in Athenas hybrid was enhanced 17 fold following phosphite treatment. Hybrid survival at juvenile stage was higher with phosphite and similar to CM 328 and 334, but this resistance reaction did not persist after transplant up to the fruiting stage.

Jackson et al. (2000) reported that phosphite indirectly induced resistance in Eucalyptus marginata inoculated by P. cinnamomi. P. cinnamomi germinated and colonized the root of the Eucalyptus host, but it was inhibited by phosphite, conferring a protection against pathogen colonization. These authors explained this indirect resistance host defense mechanism elicited by phosphite through pathogen inhibition. Homozygous resis- tance lines like Criollo de Morelos kept their genetical resistance. Phosphite application at the juvenile stage may be a useful procedure to screen susceptibles and also heterozygous from homozygous genotypes.

Data from the second trial indicated a limited inhibitory fungistatic effect on the pathogen. It is an explanation for the intermediate survival of Nathalie and Reinger after its effect worn off. Higher phosphite concentration may act directly on the pathogen to inhibit its growth and control (Perez et al., 1995; Jackson et al., 2000). The low phosphite sub-dosage $\left(1 \mathrm{~mL} \mathrm{~L}^{-1}\right)$ in the second trial after transplant was possibly not sufficient to enhance the Nathalie and Reinger hybrid resistance up to the fruiting stage.

Host resistance enhancement by phosphite was evident, when heterozygous hybrid was challenged by $P$. capsici. Further researches would be necessary to elucidate the indirect phosphite action through phytoalexin induction, like capsidiol in Capsicum (Hwang \& Sung, 1989). Phosphite can be used to screen homozygous lines resistant to $P$. capsici.

\section{ACKNOWLEDGEMENTS}

To FAPESP (Foundation of Support to the Research of the State of São Paulo) by scientific initiation fellowship grant, nov/00-nov/01 - Proc 00/ 06356-1. 


\section{REFERENCES}

BARKSDALE, T.H.; PAPAVIZAS, G.C.; JOHNSTON, S.A. Resistance to foliar blight and crown rot of pepper caused by Phytophthora capsici. Plant Disease, v.68, p.506-509, 1984.

BARTUAL, R.; CARBONELL, E.A.; MARSAL, J.I.; TELLO, J.C.; CAMPOS, T. Gene action in the resistance of peppers (Capsicum annuum) to Phytophthora stem blight (Phytophthora capsici L.) Euphytica, v.54, p.195-200, 1991.

BOSLAND, P.W.; LINDSEY, D.L. A seedling screening for phytophthora root rot of pepper, Capsicum annuum. Plant Disease, v.75, p.1048-1050, 1991.

CANDELA, M.E.; ALCAZAR, M.D.; ESPIN, A.; EGEA, C.; ALMELA, L. Soluble phenolic acids in Capsicum annuum stems infected with Phytophthora capsici. Plant Pathology, v.44, p.116-123, 1995.

ECHER, M.M. Reação de pimentão (Capsicum annuum L.) a Phytophthora capsici e Potato Virus Y (PVY $\left.{ }^{\mathrm{m}}\right)$. Piracicaba: USP/ESALQ, 2001. 62p. (Tese - Doutorado).

FENN, M.E.; COFFEY, M.D. Studies on the in vitro and in vivo antifungsal activity of Fosetyl-Al and Phosphorous acid. Phytopathology, v.74, p.606-611, 1984.

GUEST, D.I. Modification of defence responses in tobacco and Capsicum following treatment with fosetyl-Al [aluminium tris (o - ethyl phosphonate)]. Physiological Plant Pathology, v.25, p.125-134, 1984.

GUEST, D.I. Evidence from light microscopy of living tissues that fosetylAl modifies the defense response in tobacco seedlings following inoculation by Phytophthora nicotianae var. nicotianae. Physiological and Molecular Plant Pathology, v.29, p.251-261, 1986.

GUEST, D.I.; GRANT, B.R. The complex action of phosphonates as antifungal agents. Biological Review, v.66, p.159-187, 1991.

HWANG, B.K.; SUNG, N.K. Effect of metalaxyl on capsidiol production in stems of pepper plants infected with Phytophthora capsici. Plant Disease, v.73, p.748-751, 1989.

HWANG, B.K.; KIM, C.H. Phytophthora blight of pepper and its control in Korea. Plant Disease, v.79, p.221-227, 1995.

JACKSON, T.J.; BURGUESS, T.; COLQUHOUN, I.; HARDY, G.E.S. Action of the fungicide phosphite on Eucalyptus marginata inoculated with Phytophthora cinnamomi. Plant Pathology, v.49, p.147-154, 2000.

KIMBLE, K.A.; GROGAN, R.G. Resistance to Phytophtora root rot in pepper. Plant Disease Reporter, v.44, p.872-873, 1960.

MATHERON, M.E.; MATEJKA, J.C. Comparative activies of sodium tetrathiocarbonate and metalaxyl on Phytophthora capsici and root crown rot on chile pepper. Plant Disease, v.79, p.56-59, 1995.

MATSUOKA, K.; CASALI, V.M.D.; SARAIVA, T.R.C.B. Fontes de resistência a Phytophthora capsici em Capsicum annuum. Fitopatologia Brasileira, v.9, p.193-201, 1984.
ORTEGA, G.R.; PALAZON, E.C.; CUARTERO, Z.J. Response of pepper to the intravarietal selection for resistence to Phytophthora capsici. In: EUCARPIA MEETING GENETICS AND BREEDING OF CAPSICUM AND EGGPLANT, 6., Zaragoza, 1986. p.141-144.

PEGG, K.; WILEY, A.W.; SARANAH, J.B.; GLASS, R.J. Control of Phytophthora root rot of avocado with phosphorous acid. Australasian Plant Pathology, v.14, p.25-29, 1985.

PEREZ, V.; MAMDOUH, A.M.; HUET, J.C.; PERNOLLET, J.C.; BOMPEIX, G. Enhanced secrection of elicitins by Phytophthora fungi exposed to phosphonate. Cryptogamie Mycologia, v.16, p.191-194, 1995.

REIFSCHNEIDER, F.J.B.; CAFÉ-FILHO, A.G.; REGO, A.M. Factors affecting expression of resistence in pepper (Capsicum annuum) to blight caused by Phytophthora capsici in screening trials. Plant Pathology, v.35, p.451-456, 1986.

REIFSCHNEIDER, F.J.B.; BOITEUX, L.S.; VEXHIA, P.T.D.; POULOS, J.M.; KURODA, N. Inheritance of adult-plant resistance to Phytophthora capsici in pepper. Euphytica, v.2, p.45-49, 1992.

RISTAINO, J.B.; JOHNSTON, S.A. Ecologically based approaches to management of Phytophthora blight on bell pepper. Plant Disease v.83, p.1080-1089, 1999.

ROHRBACH, K.G.; SCHENCK, S. Control of pineapple heart rot, caused by Phytophthora parasitica and P. cinnamomi, with metalaxyl, fosetyl$\mathrm{Al}$ and phosphorous acid. Plant Disease, v.69, p.320-323, 1985.

SAINDRENAN, P.; BARCHIETTO, T.; AVELINO, J.; BOMPEIX, G. Effect of phosphate on phytoalexin accumulation in leaves of cowpea infected with Phytophthora cryptogea. Physiological and Molecular Plant Pathology, v.32, p.425-435, 1988.

SALA, F.C.; COSTA, C.P.; ECHER, M.M.; MARTINS, M.C.; KIMATI, H. Triagem de pimentão e pimenteiras (Capsicum spp.) visando resistência a Phytophthora capsici. Summa Phytopathologica, v.27, p.96-97, 2001./ Resumo

SMILLIE, R.H.; GRANT, B.R.; GUEST, D. The mode of action of phosphite: evidence for both direct and indirect modes of action on three Phytophthora spp. in plants. Phytopathology, v.79, p.921-926, 1989.

WILKINSON, C.J.; SHEARER, B.L.; JACKSON, T.J.; HARDY, G.E. Variation in sensitivity of Western Australian isolates of Phytophthora cinnamomi to phosphates in vitro. Plant Pathology, v.50, p.83-89, 2001.

Received July 04, 2003

Accepted July 07, 2004 